\title{
Evaluation of 2013 Curriculum Implementation of Physics Subjects Learning Outcomes
}

\author{
Martina Eryyani ${ }^{1}$ and Acep Kusdiwelirawan ${ }^{2}$ \\ \{martina.erryani@gmail.com ${ }^{1}$ \} \\ Physics Education Study Program, Universitas Muhammadiyah Prof Dr Hamka, Indonesia ${ }^{12}$
}

\begin{abstract}
This study aims to determine the implementation of the curriculum in schools with curriculum evaluation activities to determine the obstacles and constraints faced by schools so that they can be fixed and smoothen the implementation of the 2013 curriculum in schools. The research method used is qualitative research with a context, input, process, and product (cipp) evaluation model. The technique of collecting data by using triangulation (combined). The results of the 2013 curriculum implementation questionnaire, in 3 (three) schools the percentage of 1 (one) school had a percentage of $76.34 \%$, in 2 (two) schools it was $98.84 \%$, and 3 (three) schools had a percentage of $98.65 \%$. So it can be interpreted that school 2 (two) has a very good implementation of the 2013 curriculum because it has the highest percentage and school 1 (one) has the lowest percentage, which means that it has not fully implemented the 2013 curriculum. Of the three schools, the average percentage is $91.27 \%$. The results of the learning activity questionnaire, in 3 (three) schools the percentage of school 1 (one) had a percentage of $62.82 \%$, in school 2 it was $98.47 \%$, and school 3 had a percentage of $83 \%$. So it can be interpreted that 2 (two) schools have learning activities that are in accordance with the 2013 curriculum because it has the highest percentage and school 1 (one) has the lowest percentage which means that it has not fully implemented learning activities. From the three schools, the average percentage was $81.43 \%$.
\end{abstract}

Keywords: Curriculum 2013; Physics Subjects; Learning Outcomes

\section{Introduction}

Efforts to face the challenges in the era of globalization are carried out with several policies by the government, one of which is the policy in the education sector. Education is the main pillar in the development of human and community resources of a nation. Government policies in the education sector are carried out so that education in Indonesia has an increased quality. The curriculum is the main focus for the development of education in Indonesia because it is a fundamental thing needed to change the education system.

The curriculum in Indonesia has changed several times, namely the curriculum in 1947, 1952, 1964, 1975, 1984, 1994, 2004 and 2006. Curriculum changes are intended to prepare students to be better prepared for future challenges through knowledge, skills, attitudes, and skills to adapt and survive in a changing environment. The implementation of the 2013 Curriculum is a hope for the government and the Indonesian people. The change in the Education Unit Level Curriculum, abbreviated as KTSP or the operational curriculum to the 2013 curriculum, has been planned by the government with various actions. The existence of 
this curriculum development requires the readiness of various parties starting from the government and education units that implement this curriculum.

[1] said "Evaluation is a series of activities to compare the realization of inputs, outputs and outcomes against plans and standards. Evaluation is carried out on the implementation of plans to assess the success of the implementation of a program or activity based on the indicators and performance targets stated in the program or activity. According to Law Number 20 of 2003, the curriculum is a set of plans and arrangements regarding the objectives, content and learning materials, as well as the methods used as guidelines for implementing learning activities to achieve certain educational goals. Permendikbud Number 159 of 2014 [1] explains that "Curriculum evaluation is a series of planned, systematic, systemic activities in gathering and processing information, giving consideration in making decisions to improve the curriculum".

This study aims to determine the implementation of the curriculum in schools with curriculum evaluation activities to determine the obstacles and constraints faced by schools so that they can be fixed and smoothen the implementation of the 2013 curriculum in schools. Its implementation must be monitored and evaluated to find out how far the curriculum has been implemented so that later things that can hinder the implementation of the 2013 curriculum in schools can be overcome. In every school, there is a need for a curriculum evaluation to determine the level of success in achieving the curriculum. The learning outcomes of students in school can be one part of determining the success rate of curriculum achievement. [2]

The above problems are also supported by previous research conducted by Endang Surahman (2015) entitled "Implementation of 2013 Curriculum for Physics Subjects in State High Schools in Tasikmalaya City" which aims to determine the Implementation of 2013 Curriculum for Physics Subjects in State Senior High Schools throughout the city. Tasikmalaya. The method used in this research is descriptive method, with the population being all State Senior High Schools in Tasikmalaya City that have implemented the 2013 curriculum. The instruments used are a questionnaire given to teachers and students to obtain data in the form of information about the implementation of the 2013 curriculum.

In the field of education, curriculum is considered very important because the curriculum is prepared and developed to achieve its final educational goals because of the importance of the curriculum in school implementation because the curriculum is one of the keys to determining the quality of graduates, the curriculum is always evaluated for a certain period of time to be adjusted to the development of science. So, with that researcher will conduct research on the evaluation of the 2013 curriculum. In the survey results conducted by researchers in three schools in Bekasi that were accredited A, the results obtained at school A were 67\%, school B 70\%, school C 61\%, school D 64\%, school E 70\%, and school F 72\%. It can be seen from the survey results that the six schools had the highest score of $72 \%$.

Based on the results of the survey and the results of these studies, researchers are encouraged to find out the evaluation of the implementation of the 2013 curriculum on the learning outcomes of physics subjects in high schools.

\section{Theoretical reviews}

\section{a. Evaluation}

Evaluation which in English is known as Evaluation. In general, the notion of evaluation is a process to provide information about the extent to which a certain activity has been 
achieved, how the achievement is different from a certain standard to find out whether there is a difference between the two, and how the benefits that have been done are compared to expectations. to be obtained. [1] says "Evaluation is a series of activities to compare the realization of inputs, outputs and outcomes against plans and standards. Evaluation is carried out on the implementation of plans to assess the success of the implementation of a program or activity based on the indicators and performance targets listed in the program or activity.

Based on Teguh Triwiyanto's opinion, evaluation is an activity to compare a program or system to assess the successful implementation of the program or system based on its performance indicators and targets. [1] states that "Evaluation can review the progress of education and make new efforts to develop it". It can be seen that evaluation is a tool used to monitor the progress of education and carry out new efforts to develop education so that it can improve based on its indicators. According to Nana Syaodih [3] states that "Evaluation is a broad, complex and continuous activity to determine the process and results of implementing the education system in achieving predetermined goals".

Based on Nana Syaodih's opinion, evaluation is an activity that has interconnected and interdependent parts to determine the process of activities and the results of implementing an educational system or program in achieving a predetermined goal. From some of the above definitions, it can be defined that evaluation is the process of comparing a decision or policy made to assess the successful implementation of a program or activity based on performance indicators and targets.

\section{b. Curriculum}

The curriculum is derived from Latin which the root word is currere, which literally means a running field. The field has a start limit and a finish limit. In the field of education, this definition explains that the learning materials have been determined with certainty, where to begin teaching and when to end, and how to master the material in order to achieve the degree.

According to Law Number 20 of 2003, the curriculum is a set of plans and arrangements regarding the objectives, content and learning materials, as well as methods used as guidelines for implementing learning activities to achieve certain educational goals. Based on the law, it can be concluded that the curriculum is a set of learning plans that contain objectives, content, and learning materials, as well as methods used to achieve certain goals. According to Sukmadinata [1] states that "The curriculum is an educational plan, providing guidelines and guidelines on the type, scope and order of content, as well as the educational process. The curriculum directs all forms of educational activities for the achievement of educational goals.

Based on Sukmadinata's opinion, it can be concluded that the curriculum is an educational plan as a guideline in the field of education that is made in order to achieve educational goals. [4] said "The curriculum is an educational program provided to teach students. With this program the students carry out various learning activities, so that there will be changes and development of student behavior, in accordance with the goals of education and learning.

Based on Oemar Hamalik's opinion, the curriculum is a program designed for learning activities, with this program students can carry out learning activities so that behavior changes, according to learning objectives. Based on the above definitions, it can be concluded that the curriculum is an educational program that contains a set of plans, contents, and learning materials. With this program students carry out various activities and experiences provided by the school. Which can be implemented in the classroom or outside the classroom. To achieve educational goals. 


\section{c. Curriculum evaluation}

Permendikbud Number 159 of 2014 [1] explains that "Curriculum evaluation is a series of planned, systematic, systemic activities in collecting and processing information, giving consideration in making decisions to improve the curriculum". It can be seen that curriculum evaluation is a series of planned, systematic activities related to a system or an orderly arrangement in collecting and processing information, providing assessments and considerations in making a decision to perfect and improve a curriculum. According to S. Hamid Hasan's opinion [5] states that "curriculum evaluation is a systematic effort to collect information about a curriculum to be used as a consideration of the values and meaning of the curriculum in a particular context".

Based on the opinion of S. Hamid Hasan, curriculum evaluation is a form of effort to describe and formulate things regularly so as to form a system as a whole and gather information about the values and meaning of the curriculum in a situation.

\section{d. Curriculum 2013}

The 2013 curriculum is the latest curriculum launched by the Ministry of National Education starting in 2013 as a form of development from the previous curriculum, namely the 2006 curriculum or the Education Unit Level Curriculum which covers the competencies of attitudes, knowledge and skills in an integrated manner. The Ministry of Education and Culture 2013 [1] the 2013 curriculum states that "the 2013 curriculum is a further step in the development of the Computer Based Curriculum (KBK) which was initiated in 2004 and KTSP 2006 which covers the competence of attitudes, knowledge, and skills in an integrated manner".

When a program or system is created, there are goals that the program or system makers want to achieve. The program or system formulator wants a program or system that will be implemented in order to be better than the previous program or system. The new curriculum is expected to be a solution to the shortcomings of the curriculum contained in the previous curriculum.

\section{e. Learning outcomes}

Learning outcomes as evidence that someone has implemented learning in the presence of learning outcomes can be seen changes that occur after he receives a learning experience. Several experts expressed their opinions about learning outcomes, as follows:

[6] said "Learning outcomes are thanks to teacher actions, an achievement of teaching goals". Based on the opinion of Dimyati and Mudjino, learning outcomes are an influence on teacher actions based on the achievement of the teaching objectives.

Meanwhile, according to the opinion of [2]"Learning outcomes are the abilities possessed by students after receiving their learning experiences". It can be seen that learning outcomes are new abilities or knowledge obtained by students after carrying out learning activities so that they experience changes or additions in their knowledge.

Based on some of the opinions above, it can be concluded that learning outcomes are new abilities or knowledge that students acquire during the learning process. With the learning outcomes used for the final assessment of the learning activity process. The final assessment contains students' skills and habits, knowledge and understanding during the learning process, and attitudes or characters in learning activities. 


\section{Methodology}

The research method used is a qualitative method called the naturalistic method because the research is carried out in natural conditions (natural setting), also known as the ethnographic method, because initially this method is mostly used for research in the field of cultural anthropology, it is also called a qualitative method because the data collected and the analysis is more qualitative in nature and uses the CIPP evaluation model. Qualitative methods are used to obtain in-depth data, a data that contains meaning. Meaning is actual data, definite data which is a value behind the visible data.

The evaluation model according to Stufflebeam, Madaus, and Kellaghan [7] says that "The model describes the model maker's view of the concept and structure in evaluating while simultaneously providing evaluation guidelines designed to describe, provide assessment, and recommendations. The evaluation model is a model used in conducting evaluation activities based on the makers' beliefs about the evaluation concept itself.

According to [3] in the curriculum and learning book explains that the CIPP evaluation model "This model focuses on the view that the success of educational programs is influenced by various factors, including: characteristics of students, and the environment, program objectives, and equipment used, as well as the procedures and mechanisms for implementing the program itself. Curriculum evaluation in this model is intended to compare the performance or performance of various dimensions of the program with a number of certain criteria to produce judgments or considerations regarding the strengths and weaknesses of the curriculum". [8]"In qualitative research, data collection is carried out in natural settings (natural conditions), primary data sources, and more data collection techniques on participant observation, in-depth interviews and documentation". The data collection technique in this study used technical triangulation.

In general, the data obtained is qualitative data so that data analysis techniques are needed. The data analysis technique used in this study was the Miles and Huberman model. According to Miles and Huberman in [8]"activities in data analysis are divided into 3 (three), namely: data reduction, display data and data conclusion drawing / verification." In this case, data analysis is data processing by connecting the data obtained through observations that refer to the final conclusions in the study. The first stage carried out is a preliminary study. This stage consists of literature study, field study, and preparation of initial products.

In the literature study, various source books and relevant previous research results are reviewed. Field studies at six high schools in Bekasi were conducted by interviewing the vice principal of the curriculum school and looking at the learning process in the classroom.

The next arrangement of making instruments for the questionnaire. The instrument that has been made is then validated by the expert to be assessed, then the instrument is revised based on suggestions and validators. The next stage according to [8] is filling out questionnaires and interviews with school principals and physics teachers, making observations and seeing students' academic achievements. In conducting this research, the researcher does not provide treatment or does not teach students ". 


\section{$5 \quad$ Result and Discussion}

\subsection{Curriculum Implementation Questionnaire}

\section{Evaluation Context}

From the results of the first validation analysis on the context aspect which consists of 17 indicators, school policies, professional competence, competence of students, competency standards of graduates, content standards, process standards, education assessment standards, management standards, education financing standards, competency standards, curriculum, supervision, lesson plans, organization, teacher professional development, and quality improvement. After analyzing the lowest percentage indicators, namely education financing standards and teacher professional development, and quality improvement, namely 86.67\%. So, it can be said to be good, it only needs to be improved like the other indicators.

From the results of researchers to school, it was found that 3 (three) schools had a percentage of daily assessments at school 3 (three) 97\% and at schools 1 (one) and 2 (two) had $100 \%$. School 1 (one) has a from the results of researchers to school, it was found that 3 (three) schools had a percentage of daily assessments at school 3 (three) $97 \%$ and at schools 1 (one) and 2 (two) had 100\%. School 1 (one) has a percentage of the final semester assessment of $31 \%$ of an increase in learning outcomes from the percentage of mid-semester assessments. School 3 (three) has a mid-semester as.

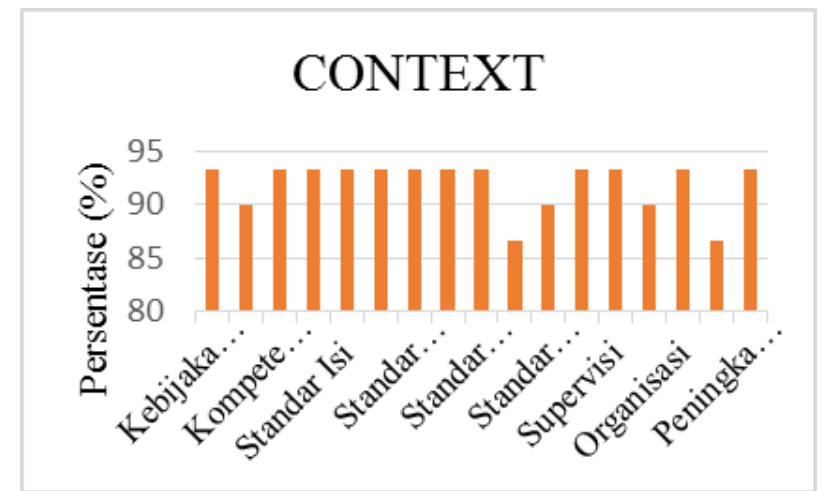

Fig 1. Evaluation of the Context of the Principal's Questionnaire

From the research findings of the context evaluation aspect in the 2013 curriculum implementation questionnaire, it can be seen that the lowest percentage of indicators are education financing standards and teacher professional development, and quality improvement, namely $86.67 \%$, which means that in 3 (three) high schools in Bekasi Regency have education and professional development financing standards. teachers, and good quality improvement.

Quality improvement in schools in terms of learning outcomes still has a low percentage of midterm and end-of-semester assessments, the highest percentage is daily assessments. The existence of learning difficulties can lead to a situation in which students cannot learn as they should so that they have low learning achievement. Students who experience learning difficulties have causal factors that affect students.

In the journal of the factors of learning difficulties for low-achieving students in grade IV public elementary schools such as ngemplak written by Novi Sanggra, it was found that the 
learning difficulty factor in the internal factors of the most dominant physiological aspect was the physical condition of students who were easily tired when studying, namely $63 \%$. From the learning difficulty factor in the internal factor, the most dominant psychological aspect is that students are less motivated in learning so that students get questions that are considered difficult by $83 \%$. From the learning difficulty factor on the external factors, the most dominant aspect of the school environment is the relationship between students and teachers, where students still feel afraid and awkward to talk / ask questions to the teacher, which is $57 \%$.

\section{Input Evaluation}

From the results of the first validation analysis on the input evaluation aspect consisting of 18 indicators, SOP, graduate competency standards, national education standards, organizational goals, national education goals, curriculum objectives, teachers, RPP format, assessment instruments, learning planning, vision and mission, PKB, professional competence, basic competence, education management, education units, education funding sources, and quality improvement planning. After analyzing the lowest percentage indicators for national education standards, $\mathrm{PKB}$, professional competence, educational units, and basic competencies, namely $86.67 \%$. So, it can be said to be good, it just needs to be improved like other indicators.

From the results of the school researchers, it was found that 3 (three) schools in Bekasi district had not fully met the national education standards which can be seen in Diagram 4.11. The low percentage of the midterm and end-semester assessments shows that only a few students can meet the minimum completeness criteria physics.

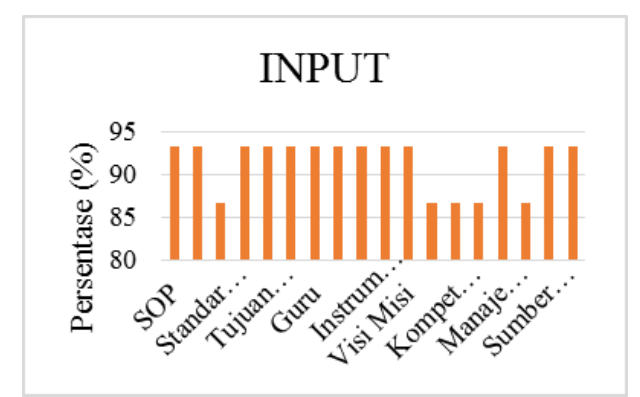

Fig 2. Evaluation of Principal's Questionnaire Input

From the research findings of the input evaluation aspect in the 2013 curriculum implementation questionnaire, it can be seen that the lowest percentage of indicators for national education standards, PKB, professional competence, educational units, and basic competences is $86.67 \%$, which means that in 3 (three) SMA Bekasi Regency have national education standards, PKB, professional competence, educational units, and good basic competencies.

So, it can be said that in 3 (three) SMA Bekasi Regency have guidelines in the implementation of education, develop teacher competence, have professional competence, and increase student learning outcomes. It can be seen in Diagram 1 that schools 2 (two) and 3 (three) have very good percentages and school 1 has the lowest percentage in the midsemester assessment and the final semester assessment shows that only a few students can meet the minimum completeness criteria. 


\section{Process Evaluation}

From the results of the first validation analysis on the aspect of process evaluation which consists of 11 indicators, the implementation of learning, planning activities, the assessment process, supervision of the principal, training, educational management, organizing, and hygiene criteria. After analyzing the lowest percentage indicator, the assessment process was $86.67 \%$. So, it can be said to be good, it just needs to be improved like other indicators.

From the results of researchers to school, it was found that school 1 (one) had daily assessments, midterm tests, and final semester tests. School 2 (two) has daily assessments, portfolios, practice, midterm tests, and final semester tests. And 3 (three) schools have daily assessments, portfolios, and final semester tests.

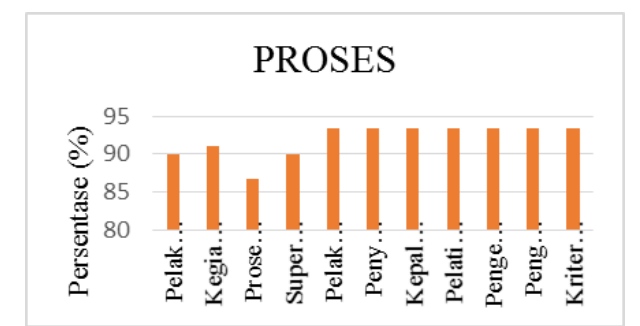

Fig 3. Evaluation of Principal's Questionnaire Process

From the research findings of the process evaluation aspect in the 2013 curriculum implementation questionnaire, it can be seen that the lowest percentage of the assessment process indicators is $86.67 \%$, which means that in 3 (three) SMA Bekasi districts have a good assessment process. Assessment in school includes written assessments, performance, products and portfolios.

At 3 (three) schools have the appropriate assessment. Schools 1 (one) have daily assessments, midterm assessments, and end-semester assessments do not have performance, product, and portfolio assessments because they do not have a physics laboratory and teaching aids. School 2 (two) have daily assessments, end-of-semester assessments and portfolios do not have midterm assessments because schools do not conduct and do not have product and performance assessments due to the covid-19 pandemic, learning is not effective.

In schools 3 (three) have daily assessments, midterm assessments, end-of-semester assessments, performance, and portfolios do not have product assessments due to the Covid19 pandemic, learning is not effective.

\section{Product Evaluation}

From the results of the first validation analysis on the aspect of product evaluation which consists of 18 indicators, graduate competence, teacher deliberation, minimal ability after graduation, minimal ability after the subject, minimal ability to master concepts, lesson plans, study load, quality improvement program, school runs effectively, organizational structure, curriculum structure, qualification results, teacher performance appraisals, qualified teachers, teacher manuals, facilities, supervision of the learning process, and learning outcomes.

After analyzing the lowest percentage indicators, the minimum ability of mastery of concepts is $86.67 \%$. So, it can be said to be good, it just needs to be improved like other indicators. 


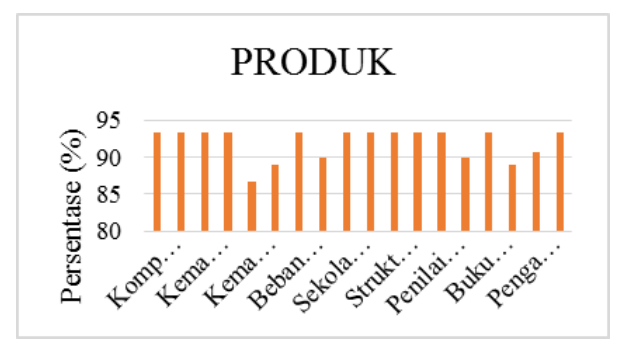

Fig 4. Evaluation of Principal's Questionnaire Products

According to Khaerul (2013: 24) in Daryl, Sutarto, Alex's june "Physics consists of concepts. The concept basically categorizes something into a non-verbal presentation, so that the concept tends to be abstract so that mental image skills are needed. Concepts are mental images and processes. A concept has a cognitive organization that is useful for solving new problems found. So, it can be concluded that understanding the concept of physics is the ability of students to know, define and describe the physics concepts they have learned without reducing their meaning. problems in the daily life of students.

From the research findings of the product evaluation aspect in the 2013 curriculum implementation questionnaire, it can be seen that the lowest percentage is the indicator of the minimum ability of mastery of the concept of $86.67 \%$ which means good. Mastery of concepts is very important for students because this is an indicator that students have fully understood what has been taught, not just memorization.

\subsection{Learning Activity Questionnaire}

\section{Evaluation Context}

From the results of the first validation analysis on the evaluation aspect of the context which consists of 12 indicators, principal policies, competence of students, facilities and infrastructure, teachers, learning management, teaching aids, learning, facilities, learning media, learning motivation, students' success rates, and assessment. After the analysis was carried out in the lowest percentage indicator, the props were $67 \%$.

From the results of the researchers conducting the research, it was found that school 2 (two) and school 3 (three) had teaching aids and school 1 (one) did not have teaching aids for learning physics.

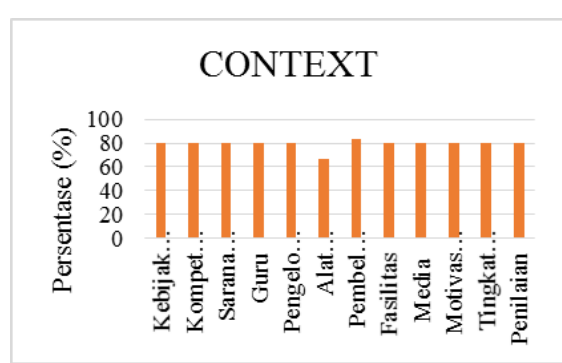

Fig 5. Evaluation of Teacher's Context Questionnaire

From the research findings, the evaluation context aspect of the learning activity questionnaire shows that the lowest percentage of the teaching aids indicator, namely $67 \%$, means that there needs to be an increase in using teaching aids in carrying out learning. The 
availability of adequate teaching aids will support an interesting and fun learning process. The use of teaching aids in the learning process as a tool to create an effective learning atmosphere, makes it easier for students to understand the material presented by the teacher so that the information transfer process will take place faster and improve student learning outcomes.

\section{Input Evaluation}

From the results of the first validation analysis, the input evaluation aspect consists of 10 indicators, learning objectives, educational objectives, learning materials, learning strategies, learning materials, characteristics of physics lessons, lesson plan format, learning planning, knowledge of laboratory tools, and basic competencies. After analyzing the lowest percentage indicator, namely the $76 \%$ learning strategy.

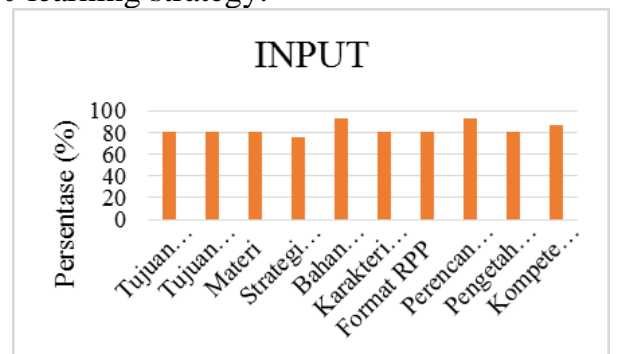

Fig 6. Evaluation of Teacher's Questionnaire Input

From the research findings of the input evaluation aspect of the learning activity questionnaire, it can be seen that the lowest percentage of the learning strategy indicator is $76 \%$, which means that there needs to be an increase in using strategies in teaching, learning strategies are the methods that will be selected and used by a teacher to deliver learning material which aims to make it easier for students to receive and understand learning material, which in the end the learning objectives can be mastered effectively and efficiently.

\section{Process Evaluation}

From the results of the first validation analysis on the evaluation aspect of the process which consists of 8 indicators, the implementation of learning, learning in the laboratory, making learning plans, making learning strategies, supporting learning processes for students to be active, compiling test instruments, determining learning resources, and teachers determine the learning media. After the analysis is carried out in the lowest percentage indicator, that is, learning in the laboratory is $75.56 \%$.

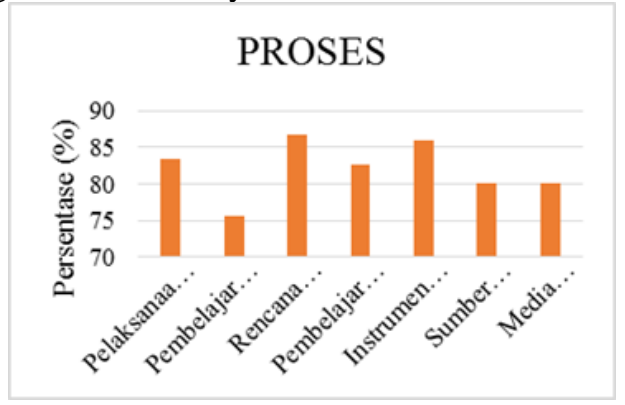

Fig 7. Evaluation of the Teacher Questionnaire Process 
From the results of the researchers conducting the research, it was found that only school 3 (three) conducted learning in the laboratory, school 2 (two) and school 1 (one) did not use the laboratory for learning but school 2 (two) continued to carry out practice and portfolios in the classroom.

From the research findings, the process evaluation aspect shows that the lowest percentage of learning indicators in the laboratory is $75.56 \%$, which means that there needs to be an increase in learning in the laboratory. The laboratory is one of the learning infrastructures that can be used as a place to train students to understand concepts and improve skills in conducting scientific experiments. With students doing learning in the laboratory, it makes it easier for students to understand all science that is still abstract so that it becomes something concrete and real.

\section{Product Evaluation}

From the results of the first validation analysis on the aspect of product evaluation which consists of 12 indicators, affective abilities, scientific approaches, students have cognitive, affective, and psychomotor abilities as a result of learning, students can be active during learning, learning media, learning strategies to improve student learning outcomes, learning resources to make it easier for students in the learning process, modules to make it easier for distance learning, teaching methods, evaluating learning outcomes, tests as learning evaluations, and student achievement will be better. After analyzing the lowest percentage indicator of learning strategies to improve student learning outcomes, namely $77.83 \%$.

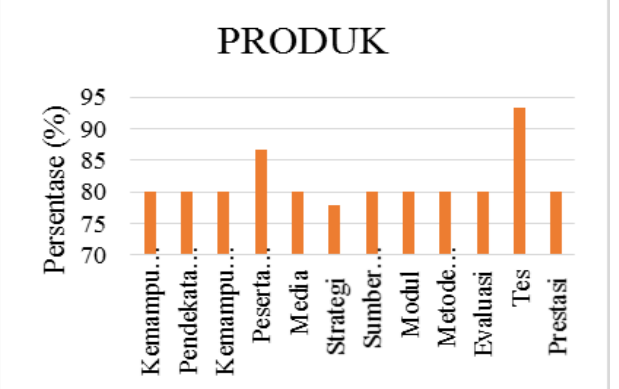

Fig 8. Teacher Questionnaire Product Evaluation

From the research findings of the product evaluation aspect, it can be seen that the lowest percentage of indicators for learning strategies to improve student learning outcomes is $77.83 \%$, meaning that there is a need for an increase in learning strategies to increase student learning outcomes. The teacher plays an important role in improving learning outcomes obtained by students, a teacher who plans an effective and efficient learning model. Teachers need to design learning activities that can stimulate the creation of more effective and efficient learning, a strategy is needed to convey it. 


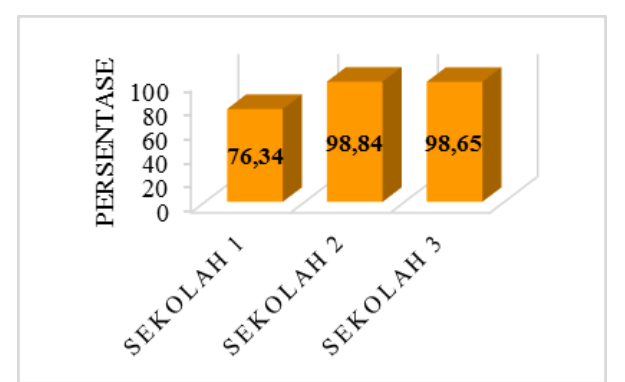

Fig 9. Results of the Principal's Questionnaire

In this study, the results obtained are from the implementation of the 2013 curriculum at SMA 4 Babelan, SMA 2 Babelan, and SMA Islam Pb. Sudirman 2 Bekasi is said to be very good, as evidenced by the percentage results shown in Graph 4.9. Therefore, the results of research conducted by researchers prove that out of 3 (three) high schools in Bekasi Regency have a very good implementation of the 2013 curriculum.

From the results of researchers from 3 (three) schools, it was found that in school 1 (one) had a standard percentage of $75 \%$ and the results of research $76.34 \%$ which showed the implementation of the 2013 curriculum exceeded the percentage of school standards. School 2 (two) has a standard percentage of $90 \%$ and the results of research are $98.84 \%$ which shows the implementation of the 2013 curriculum has exceeded the percentage of school standards. And 3 (three) schools have a percentage of $99 \%$ and the results of the research are $98.65 \%$ which show that the implementation of the 2013 curriculum is less than the percentage of school standards.

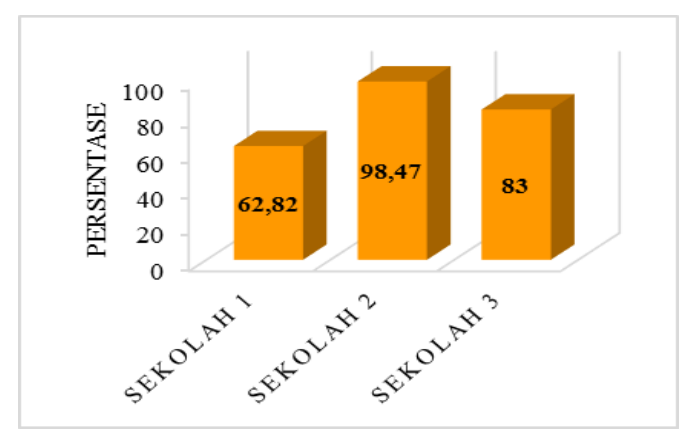

Fig 10. Teacher Questionnaire Results

From the results of the analysis on the learning activity questionnaire, the average percentage was $81.43 \%$ and school 1 (one) had a percentage of $62.82 \%$ which was categorized as good, at school 2 (two) namely 98.47\% was categorized as very good, and school 3 (three) had the percentage that is $83 \%$ is categorized as very good. Therefore, the highest percentage was at school 2 (two) with a percentage of $98.47 \%$ and the lowest percentage was at school 1 (one), namely $62.82 \%$.

In this study, the results obtained from learning activities at SMA 4 Babelan, SMA Negeri 2 Babelan, and SMA Islam $\mathrm{Pb}$. Sudirman 2 Bekasi is said to be very good, as evidenced by the percentage results found in Diagram 4.10. Therefore, the results of research that have been conducted by researchers prove that out of 3 (three) SMA Bekasi districts have excellent learning activities. 


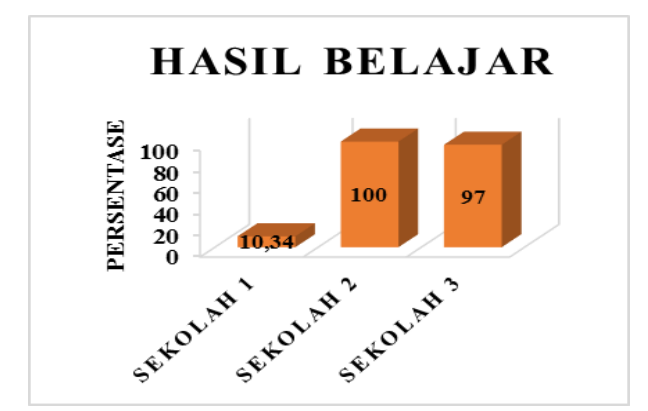

Fig 11. Learning outcomes

In this study, the learning outcomes of students on the national minimum completeness criteria in physics subjects were 70, so it was found that 3 (three) schools, namely 1 (one) school had daily assessments, midterm and end-semester assessments found that the average score -The average of the 3 (three) percentage assessments is $10.34 \%$ of students who reach the minimum completeness criteria. School 2 (two) has daily assessments, portfolios, and endof-semester assessments, it is found that at the average value of the 3 (three) assessments the percentage is $100 \%$ of students who reach the minimum completeness criteria.

School 3 (three) has daily assessments, portfolios, practices, midterm assessments, and end-semester assessments, it is found that the average score of the 5 (five) assessments is $97 \%$ of students who achieve the minimum completeness criteria. It can be seen in Diagram 4.11 that the highest percentage is school 2 (two) and the lowest percentage is school 1 (one). From the results of research in 3 (three) schools in Bekasi district, it was found that at school 2 (two) and school 3 (three) the implementation of the 2013 curriculum could improve student learning outcomes. And at school 1 (one) it can be seen that the implementation of the 2013 curriculum has the lowest percentage and the lowest percentage of students who reach the minimum completeness criteria due to school 1 (one) has just been established in 2019 several indicators need to be improved again so that the 2013 curriculum can be maximally implemented, but for schools that have just been established, 1 (one) school is classified as good.

\section{Conclusion}

Curriculum evaluation activities to determine the obstacles and constraints faced by schools so that they can be repaired and facilitate the implementation of the 2013 curriculum in schools. By using questionnaire techniques, interviews, observation, and documentation. Based on the results of research conducted at three high schools in Bekasi district, it was found that out of three schools, one school had the lowest percentage in the implementation of the 2013 curriculum which had not been able to improve student learning outcomes based on the national minimum completeness criteria for physics subjects and several indicators needed to be improved. return to the implementation of the 2013 curriculum optimally, but for new schools that are established one year it is considered good. 


\section{References}

[1] Triwiyanto, T. (2015). Curriculum Management and Learning. Jakarta: Earth Literacy.

[2] Sudjana, N. (2006). Assessment of Teaching and Learning Process Results. Bandung: PT Remaja Rosdakarya.

[3] Ruhimat, et al. (2017). Curriculum and Learning. Depok: Rajawali Press.

[4] Hamalik, O. (2012). Curriculum and Learning. Jakarta: Earth Literacy

[5] Yani, A. (2014). 2013 Curriculum Mindset. Bandung: Alfabeta.

[6] Dimyati, and Mudjiono (2013). Learning and Learning. Jakarta: Rineka Cipta.

[7] Anidi (2017). Evaluation of Learning Programs. Yogyakarta: Parama Publishing.

[8] Sugiyono (2016). Quantitative Research Methods, Qualitative, and Development. Bandung: Alfabeta. 